\title{
Addressing the eLearning Contradiction: A Collaborative Approach for Developing a Conceptual Framework Learning Object
}

\author{
Colla Jean MacDonald, Emma Stodel, Terrie Lynn Thompson \\ University of Ottawa, Ottawa, Canada
}

\author{
cjmacdon@uottawa.ca estodel@rogers.com \\ tlthompson@rogers.com \\ Bill Muirhead, Chris Hinton, Brad Carson, Erin Banit \\ University of Ontario Institute of Technology, Toronto, Canada
}

\author{
bill.muirhead@uoit.ca chris.hinton@uoit.ca \\ brad.carson@uoit.ca erin.banit@uoit.ca \\ Abstract
}

In many universities there seems to be an "eLearning Contradiction" between the expressed need to integrate technology into the teaching-learning process and what is actually occurring in the majority of classrooms. In this paper we describe the collaborative process we used to design an online Conceptual Framework Learning Object (C-FLO). The object can be viewed at http://innovation.dc-uoit.ca/cloe/lo/cf/ This account is grounded in practical experiences and supported by the research literature. First, we offer a rationale for the development of C-FLO. We then illustrate how an interdisciplinary collaborative perspective enhanced both the process and learning outcomes. The impact of this learning object from both the learners' and professors' perspectives is detailed. Collaborative projects such as C-FLO, where professors share resources and expertise to improve student learning, could be a first step toward addressing the eLearning Contradiction.

Keywords: learning objects, higher education, e-learning, collaboration, conceptual frameworks

\section{Introduction}

\section{The Transformation of Education through Technology}

In the past decade, educational theorists have described how technology has transformed, and will

Material published as part of this journal, either on-line or in print, is copyrighted by the publisher of the Informing Science Journal. Permission to make digital or paper copy of part or all of these works for personal or classroom use is granted without fee provided that the copies are not made or distributed for profit or commercial advantage AND that copies 1) bear this notice in full and 2) give the full citation on the first page. It is permissible to abstract these works so long as credit is given. To copy in all other cases or to republish or to post on a server or to redistribute to lists requires specific permission and payment of a fee. Contact Publisher@ijklo.org to request redistribution permission. continue to transform, education (e.g., Eastmond \& Ziegahn, 1995; Fitch, 2004; Haughey \& Anderson, 1998; Kearsley, 1996; Khan, 1997; MacDonald \& Gabriel, 1998; MacDonald \& Thompson, 2004; Romiszowski, 1997). Without a doubt, technology has offered viable alternatives to the traditional teaching-learning process as ongoing advancements continue to offer new avenues for learning 
(Burge, 2001a, 2001b; Burge \& Haughey, 2001; DeBard \& Guidera, 2000; Stodel \& Farres, 2002; Wiley, 2000). The Internet has also greatly influenced the way educational materials are being designed, developed, and delivered (Canada, 2000; Conference Board of Canada, 2000, 2001; Land \& Hannafin, 2000; McConnell, 2002; Salmon, 2000).

In 1997, Drucker postulated that higher education was in deep crisis and claimed that university buildings are "hopelessly unsuited and totally unneeded" (p. 127). His comment was based on the observation that institutions of higher learning are insensitive to the changing demographics of the university learner. He suggested that the antiquated processes of admissions and registration, as well as fixed meeting places and times for classes, indicate that institutions are not responding to the needs of their clients, nor are they taking advantage of universally available access to communication technologies.

Drucker (1997) was not alone in his predictions. Around the same time, other educators were also suggesting that the university customer had changed, and would continue to change- a shift driven by the forces of our knowledge-based economy (Moe \& Gay, 1997; Romiszowski, 1997). In line with these changes and in the midst of rapid technological change, Eastmond and Ziegahn (1995) suggested that university students who might once have been willing to tolerate the inconveniences of post-secondary education would soon be demanding new approaches to education. Although some research-practitioners saw technological advancements as a means to replace the "brick and mortar university," others recognised that, for some, the "campus experience" is an important aspect of university education (MacDonald, Stodel, Farres, Breithaupt, \& Gabriel, 2001). However, MacDonald et al. recognised that learning online may be a preferred approach for working adults or adults with families or who live in remote locations.

\section{The "eLearning Contradiction"}

A look around many Canadian universities in 2005, eight years after Drucker's (1997) prediction that university buildings are "totally unneeded", suggests that the "brick and mortar growth" within universities is thriving, contrary to the claims of visionaries almost a decade ago. Nonetheless, there are many educational technology innovations occurring in university Centres of Learning and technological initiatives are being taken by some professors. However, in many universities across Canada there is what we term the "eLearning Contradiction". By this we are referring to the contradiction between the expressed need to integrate technology into the teaching-learning process to enhance learning and what is actually occurring in the majority of university classrooms. This contradiction might be a result of the fact there is little incentive for professors to devote the hours required to design technology-based resources when their teaching scores with traditional delivery methods suffice to obtain tenure and promotion. Further, professors may feel that their time is better spent securing research grants and publishing.

MacDonald and Thompson (2004) found that designing quality online courses takes an enormous amount of time for upfront planning as well as painstaking attention to detail. They suggested that the drive to create online courses is often due to the determination of the professor, his/her ability to marshal the necessary resources, and his/her relative aversion to risk. Developing technologybased resources needs to be made easier, quicker, and more efficient if professors trying to meet the challenges of tenure and promotion are expected to address the eLearning Contradiction. The need for more systematic and strategic approaches to educational technology innovation and implementation resounds in the literature (McGorry, 2003; Parrish, 2004). In this paper we not only support the extant literature by agreeing that new methods of teaching are necessary, but we go a step further and suggest that new and more efficient methods of designing and developing technology resources are required to meet the needs of today's university professor. 


\section{The Learning Object Solution}

Learning objects are small instructional components that can be reused a number of times in different learning contexts. They provide many enhancements and benefits to the learning process: (1) an alternative way to learn that is engaging, interactive, and fun; (2) flexibility and convenience because they can be accessed at any time and from anywhere there is an Internet connection; and (3) a way to save time and resources as they can be reused and adapted by different users, with new versions available immediately. This flexibility, or interoperability, is well documented in the literature. Richards and Hatala (2003) explained, "in a web-based learning objects environment these elements [content and activities] are generally kept as discrete files that can be inserted or transmitted as required by an instructional plan” (p. 366).

In addition, the web-based nature of learning objects means that any number of people can access and use them simultaneously. The potential for reusability, adaptability, and scalability make learning objects a possible solution to many of the issues associated with the eLearning Contradiction and the technology of choice in the next generation of instructional design, development, and delivery (Gibbons, Nelson, \& Richards, 2000; Hodgins, 2000; Urdan \& Weggen, 2000).

The merits of learning objects are prevalent in the literature. However the definitions, processes, and procedures of developing learning objects are still ill-defined. Far from being just an effort to create instructional materials, learning objects also require more important changes to how education is delivered on- and off-campus (Ally, 2004; Downes, 2004; Muirhead \& Haughey, 2003; Porter, Curry, Muirhead, \& Galan, 2002). The use of high quality, interactive learning materials suggests that the traditional "stand and deliver" mode of instruction will likely change to one where students are exposed to rich online virtual learning environments (VLE). VLEs are defined as software tools that bring together, in an integrated environment, a range of resources that enable participants to interact online and include content modules and tracking of student activity and achievement (Hunt, Parsons, \& Fleming, 2003). Most course management systems such as WebCT and Blackboard are VLEs. VLEs are characterized as highly interactive, with the potential for instructors and learners to explore knowledge and skill acquisition through interactions with the material and each other. In such environments learning objects can easily be included to further enhance both interactivity and the learning process.

Possibly the least well understood attribute of learning objects involves the learner's role as explorer. There is a shift away from didactic instruction to discovery of information (Smaldino, 1999). This approach aligns with the constructivist philosophy of learning where the learner is encouraged to participate in and interact with the environment to construct individual meaningful knowledge. This learner-centred or constructivist approach (Hill, 1997; Jonassen, 1994; Jonassen, Peck, \& Wilson, 1999; Relan \& Gillani, 1997) seems to be particularly suitable for learning objects.

An attribute of learning objects directly arising from the active role of the learner is the opportunity for interaction. Interactions allow learners to tailor learning experiences to meet their specific needs or abilities. Being able to control the pace of their learning, learners have time to reflect and process information (Stodel \& Farres, 2002). In addition, interactions foster learners' intrinsic motivation by highlighting the relevancy any new information may have under specific circumstances (Wagner, 1997).

\section{The C-FLO Project}

This project involved the development of an online learning object designed to support and guide learners in the process of writing research questions and developing a conceptual framework that can be used to frame research papers and/or theses and dissertations. We termed this object CFLO. The need for C-FLO emerged from years of practical teaching experience at Canadian uni- 
versities. The project began with one professor, Colla MacDonald, working in isolation and, over several years, evolved into a collaborative effort involving professors, a post-doctoral fellow, a graduate student, instructional designers, and programmers from different universities. The real names of the individuals involved in this project will be used throughout this paper; they are also the authors of the paper.

Colla has taught in universities for twenty years. Her experience revealed that many learners are ill-prepared to write well-structured papers that are guided by a solid conceptual framework and follow a convincing line of argument. Ten years ago she began asking learners to design a conceptual framework to guide their research process - whether it was for an assignment in a teacher education course, writing a research paper for a graduate course, or planning an M.A. or Ph.D. thesis. Learners at all levels consistently reported that they found the process of designing a conceptual framework demanding, abstract, and frustrating. Colla's discussions with other professors revealed that this was a common problem among learners. However, when the learners finally completed their conceptual frameworks, they unanimously agreed that it clarified and directed their research process - guiding their writing, keeping them on track, saving them time in the long run, and enabling them to defend their arguments soundly and readily.

The feedback received from learners and professors suggested that the practice of developing a conceptual framework was a critical component of the research process, yet there were no support documents or resources readily available to assist learners and professors with this complex task. Moreover, like most professors, Colla planned, taught, and delivered her teaching alone, so not only was there little support for learners, there was also little support for the professor. The pedagogical challenge was therefore to determine how the process of developing a conceptual framework could be made more meaningful and less stressful, frustrating, and abstract for the learners. At the same time, it was anticipated that providing learners with better resources would mean less of a demand would be placed on the professor's time so he/she could spend his/her time engaged in a higher level of discussion with the learner regarding his/her topic, rather than being distracted by a poorly developed framework. Such a learning tool would be valuable in courses and programs offered in diverse faculties in almost every college and university across Canada. Hence, the need for this project emerged.

The main objective of C-FLO is to improve student learning by supplementing and enhancing the professor's instruction and guiding learners in any discipline in the process of developing a conceptual framework, which can then be used to frame research papers, reports, and theses. By providing criteria for expected rigor and examples of completed products, the learning object provides a standard that will facilitate the creation of superior quality conceptual frameworks. Specifically, the goals of C-FLO are to:

- Guide learners in the writing of research questions;

- Provide learners with a starting point for the conceptual thinking required when writing research papers in undergraduate, masters, and doctoral programs;

- Provide learners with step-by-step procedures and concrete examples to make the process of creating a conceptual framework less abstract;

- Allow learners to produce better quality conceptual frameworks in less time;

- Reduce learner stress and anxiety commonly associated with designing conceptual frameworks;

- Improve the quality of learners' writing by providing a framework that will guide their entire research writing process; 
- Increase learner knowledge and understanding of conceptual frameworks; and

- Supplement and enhance professors' instruction.

\section{Conceptualizing a Learning Object}

Learners are required to be active participants in developing this learning object as they work through the process of designing a conceptual framework. A 'journey' metaphor is used to transform this typically abstract task into an engaging logical process. The journey begins by introducing the characteristics of good research questions. Supported by a dynamic display of the development process, learners are then provided with step-by-step guidelines on how to develop a conceptual framework. To help situate these guidelines in a real context, C-FLO includes video clips of a learner sharing her experiences, reflections, and tips for developing conceptual frameworks at each step of the process. Furthermore, concrete examples of learners' conceptual frameworks are included. To create this engaging multimedia learning experience, Macromedia Flash software was used to design C-FLO.

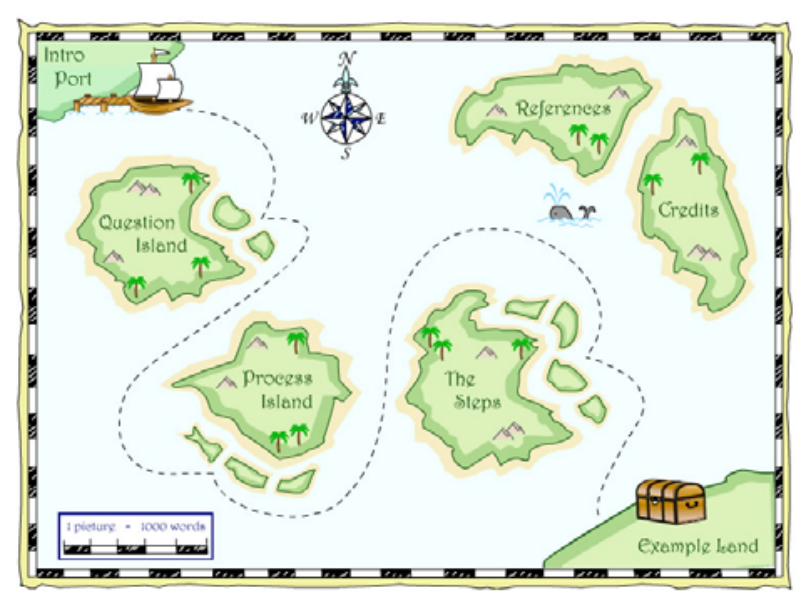

Figure 1. The C-FLO interface

In this creative learning environment, learners board a ship at Intro Port and journey through the ocean stopping at Question Island, Process Island, and The Steps on the way to their final destination of Example Land, with options to detour to the islands of References and Credits on the way (see Figure 1). While there is a definite process, learners can explore this learning object in a non-linear and non-sequential manner by visiting the islands in any order, spending as long as they wish at each island, and going back to previously visited islands at any time.

C-FLO has been implemented in four different learning settings: in two online graduate courses in the Faculty of Education at the University of Ottawa (UofO); in two sections of a face-to-face course in the B.Ed. program at the same university; and with various M.A. and Ph.D. students in their thesis work. In the online courses C-FLO is supported by both asynchronous and synchronous communication tools to facilitate the learning process. In the face-to-face courses the professor is able to provide any required support in person.

EDU5199 is the tenth and final course in the Faculty of Education's M.Ed. program. C-FLO was integrated into the online version of this course in Fall, 2004. There were 15 learners in the course from across Canada and the United States. Students were required to draw upon what they had learned in their previous nine courses and write a research paper on a topic of interest to them that relates to issues they face in their workplace. One requirement was that learners include a conceptual framework in their paper. Learners were instructed to visit C-FLO as often as they needed until they understood what a conceptual framework is, why it is important they develop one, and how to develop one. Once learners had a first draft of their conceptual framework they were asked to share it with their learning triad members who had to download and complete a feedback form. In providing feedback the learners had to state what they thought the main variables in the framework were, the areas the author wanted to research further, what the author did well, how the conceptual framework could be made stronger, an idea for the diagram and the write-up, and a 
resource that may be useful for the author. Learners were then required to incorporate any appropriate feedback and submit their conceptual framework and feedback forms to the professor.

C-FLO was also incorporated into the online version of EDU5190 that is currently being delivered to 24 learners. In this course the learners are required to complete four assignments, one of which is to develop a conceptual framework. As with EDU5199, learners are encouraged to use C-FLO as often as they wish and required to share their draft conceptual frameworks with their triad members to obtain feedback before submitting it to the professor.

In PED3103, C-FLO was used to aid learners design a curriculum model to succinctly portray their teaching philosophy and classroom strategies. This model is intended to be used by the student teachers to prepare for and present their ideas in a professional and sophisticated manner during job interviews. Although this was not a required element of the course many students did use C-FLO to this end and provided feedback on its utility.

Lastly, C-FLO has been made available to M.A. and Ph.D. students in various stages of their programs to help them develop conceptual frameworks that they have subsequently integrated into their comprehensive exams, proposals, and/or theses. Because C-FLO is available online, anyone can access it at any time and any place and as often as they wish.

\section{Why was a Collaborative Approach Necessary?}

Neither the idea to develop C-FLO nor the adoption of a collaborative approach was conscious decisions made by the team prior to the start of the project. The need for C-FLO and the benefits of developing it as a collaborative effort slowly evolved over time. The whole concept grew out of the efforts of one professor attempting to meet the needs of her learners. A collaborative approach was preferable for a number of reasons. Working as a team enabled the sharing of knowledge and expertise, thereby promoting collegiality and accomplishing more than could be achieved working independently. For example, the Ottawa team did not have the technology expertise to design C-FLO the way the team envisioned and so relied on the expertise and experience of the Toronto group in order to create a more technologically sophisticated learning object that met the pedagogical goals. Conversely, the Toronto group tended to have more experience regarding the content. The collaborative approach involved a process that recognised the unique knowledge, experience, and strengths that each member of the team brought.

\section{What were the Stages in the Collaborative Development Process?}

In hindsight there were three distinct phases to the development of C-FLO: (1) creating a paperbased document for a face-to-face class; (2) re-purposing this document into an electronic resource for an online course; and (3) creating a vibrant, rich, interactive online learning object that can be used in many different learning environments. It was in the third stage that the collaborative process became much more extensive and essential.

\section{Phase 1}

In 1998, EDU5199 was taught face-to-face and required learners to write a research paper guided by a conceptual framework. To help learners develop their conceptual frameworks Colla developed a handout outlining what a conceptual framework is, a rationale for why it is important to develop a conceptual framework, and step-by-step procedures to guide the learners in the development of a conceptual framework.

The learners appreciated this resource and felt it supported their learning. Yet while it provided learners with a better understanding of how to develop a conceptual framework, many still had 
multiple questions regarding the process and still found it a challenging and stressful task. It became clear that additional efforts needed to be made to further demystify the process of developing a conceptual framework.

\section{Phase 2}

The next year, Colla and Terrie Lynn took the initiative to develop EDU5199 online and it became the first online course in the Faculty of Education at the UofO. Again, learners were required to write a research paper that included a conceptual framework. The handout from the face-to-face class was refined and transformed into an electronic resource. In addition, learners were provided with online access to examples of conceptual frameworks to give them a clearer idea of the expectations. Although this approach was an improvement over the preceding year, learners still reported frustrations and difficulties with the task and it was evident that a better solution was needed.

\section{Phase 3}

To create C-FLO several individuals who had previously collaborated on various projects came together to form the project team. One of the most notable outcomes of this early collaborative effort was the realisation that the strengths, knowledge, skills, and expertise of the team members complemented one another superbly and resulted in a far better learning product than would have been possible if the members had worked independently. The opportunity to collaborate once again came when the Co-operative Learning Object Exchange (CLOE) supported the design of a third learning object, which turned out to be C-FLO.

For the current C-FLO project, seven people came together to form the project team. Dr. Emma Stodel, a Post-Doctoral Fellow in the Faculty of Education at the UofO, and Terrie Lynn Thompson joined Colla to form the Ottawa contingent. Bill Muirhead, Chris Hinton, Brad Carson, and Erin Banit, all from UOIT, became the Toronto contingent. The team members were selected because they enjoyed working together, had a solid track record of producing results, and had many complementary skills, including creative teaching and learning ideas, content knowledge, curriculum design expertise, real-life experiences supporting learners as they built conceptual frameworks, and multi-media production and programming skills.

Phase 3, the actual development of C-FLO, comprised three stages: pre-workshop, workshop, and post-workshop.

Pre-workshop: Once the project team agreed upon the need to develop C-FLO, several additional meetings and conference calls took place to further define the project, determine budgets, and establish roles and responsibilities. The team then entered the pre-workshop stage where much upfront work was completed. Team members communicated via telephone conferencing and email.

The development of C-FLO presented instructional design and technical challenges. The original handout on developing conceptual frameworks did not readily suggest a learning object solution. It was not clear where to begin with this project and what value could be added by the creation of a learning object. However, there was a pedagogical challenge to be addressed because learners perennially had difficulty in creating their own conceptual frameworks and reported significant stress. As the team brainstormed, the need to come up with ways to demystify the process of developing a conceptual framework emerged. It became apparent that the steps for developing a conceptual framework described in the handout needed to be broken down even furtherelaborating some, adding others-so that the overall process was more detailed and selfexplanatory. 
The activity component of C-FLO was challenging because doing so required the development of new practical material to reinforce and to support the theoretical content. The inclusion of audio and video was proposed. This led to the idea that perhaps a student's reflection on the experience of developing a conceptual framework would help learners understand that designing a conceptual framework is a complex process and validate the feeling of being lost, frustrated, and confused. By adding this support dimension to the learning object in addition to the rationale, steps, and examples, we felt we would create a superior learning experience.

Terrie Lynn had recently gone through the process of developing a conceptual framework for her M.A. thesis and had documented the process. She had also kept her hand drawn drafts of her conceptual framework (see Figure 2). As a result, she was the logical choice for narrating this aspect of C-FLO.
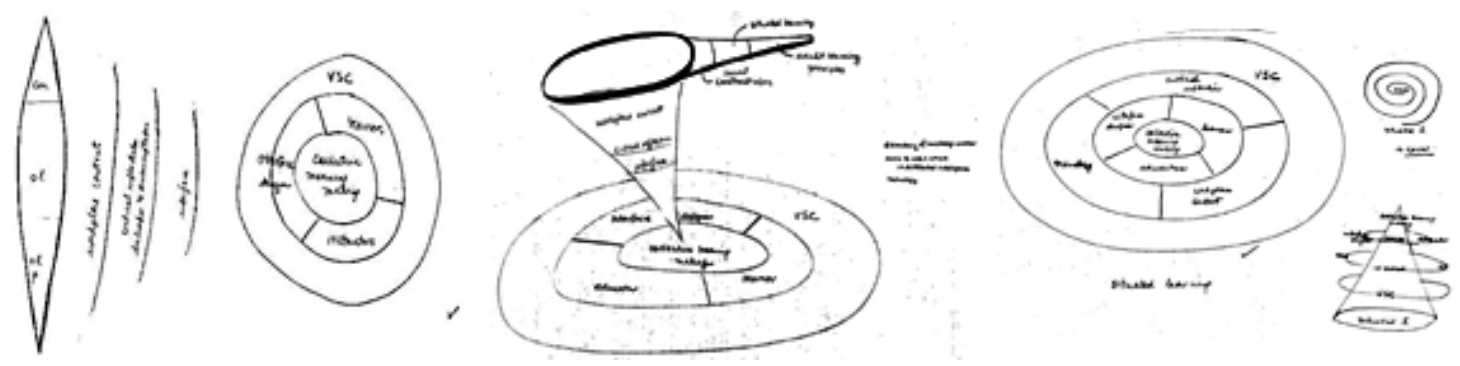

Figure 2. Various drafts of the narrator's conceptual frameworks

The team then had to decide how to present the content in a learning object. Early design suggestions applied a book metaphor to the interface design. There were to be three sections of the book - theory, tasks, and examples. The team envisioned a theory section that had Internet resources, video, discussion, epistemology, a bibliography, and approaches. The task section would include a series of exercises where the learner would be coached through the process of building their own framework. Lastly, in the example section learners would be provided with a number of previously developed frameworks. However, it was quickly apparent that this initial plan was too large and difficult to design to be practical and that new ideas needed to be explored.

Workshop: The team met for a one-day workshop to finalise the design of the learning object and video-tape Terrie Lynn talking about her experiences. The team started by reviewing the steps of how to develop a conceptual framework. The term "steps" got us thinking and there was a lot of discussion on semantics-perhaps "milestones" should be used instead and we could then use pictures of (mile)stones to show the learners' progress. The notion that developing a conceptual framework is like a journey emerged and this metaphor was pursued. The idea of the map and the ship was suggested and the team was very excited. Thoughts were presented on how to do this effectively. Ideas flew among the team members and the team, who had been sitting around the table, were soon all standing and moving around the room as the energy of the interaction and possibilities were presented. The feeling in the room was a rare intellectual excitement that results when ideas are exchanged, accepted, extended, and built upon. It was apparent that everyone was enjoying themselves from the smiles, laughter, and excitement. Often the Ottawa team got carried away with ideas and the Toronto team, who were going to have to implement the ideas, needed to rein them in so the project remained manageable and could be accomplished within the budget and timelines.

During the workshop Chris videotaped Terrie Lynn as she talked about her experience. The video session was fairly informal with questions being asked as she talked and others on the team add- 
ing comments and conferring on various aspects of the process. The video had a freshness and spontaneity that is often difficult to achieve and which added significantly to its viewability.

Post-workshop: The post-workshop stage saw the development of the learning object. The Toronto group conducted an initial rough edit on the video and, after wrestling with the viability of streaming video, came up with technology solutions to ensure that the learning object would not be too big and difficult to use. The video footage naturally chunked the material and ultimately shaped the design of C-FLO. The map metaphor conceived during the workshop was developed to portray a visual representation that linked the process of designing a conceptual framework to a journey of discovery. Children's books were used as inspiration. The final learning object took on a "coaching" character by providing the theory, a real case study that includes much valuable advice, and 20 examples of completed conceptual frameworks (see Figure 3). Navigation features enable learners to use the learning object in either a tutorial mode or as a reference, thus supporting a constructivist model of learning.

Once the Toronto group completed the development of C-FLO, the Ottawa group provided the detailed review and testing of the learning object to ensure it was user-friendly, intuitive, engaging, and accurate. This feedback was used to finalise the learning object for release.

Conceptual Framework Challenges in Changing Organizational Culture

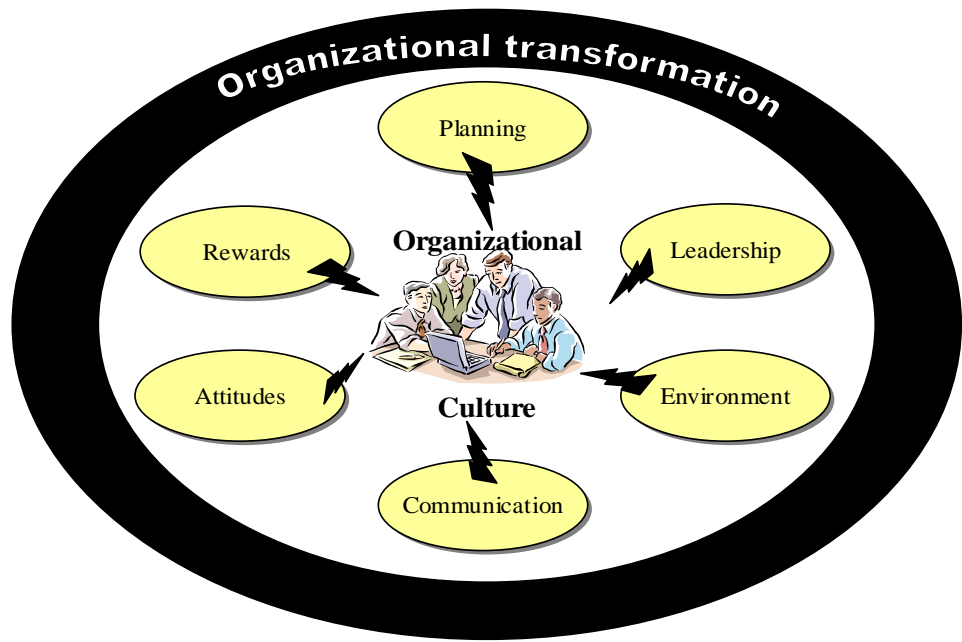

The process to achieving organizational change is typically met by a number of challenges. Frequently, these challenges are related to planning, leadership, environment, communication, attitudes and rewards. These challenges act as forces in motion and can impact organizational change (Kanter, Stein \& Jick, 1992; Beer \& Nohria, 2000). Leaders should anticipate and recognize challenges that may become barriers to achieving the desired change. Change is defined as "an alteration in actions that is produced by changes in choices made, not intentions espoused" (Martin, 2000, p. 455). Conversely, organization transformation is "the application of behavioral science theory and practice to effect large-scale, paradigm-shifting organizational change ... which usually results in totally new paradigms or models for organizing and performing work” (French, Bell \& Zawacki, 1994, p. 1). When challenges result in impeding the desired change, organizational transformation is adversely affected. Consequently, change and organizational transformation are linked and should be managed as such. 


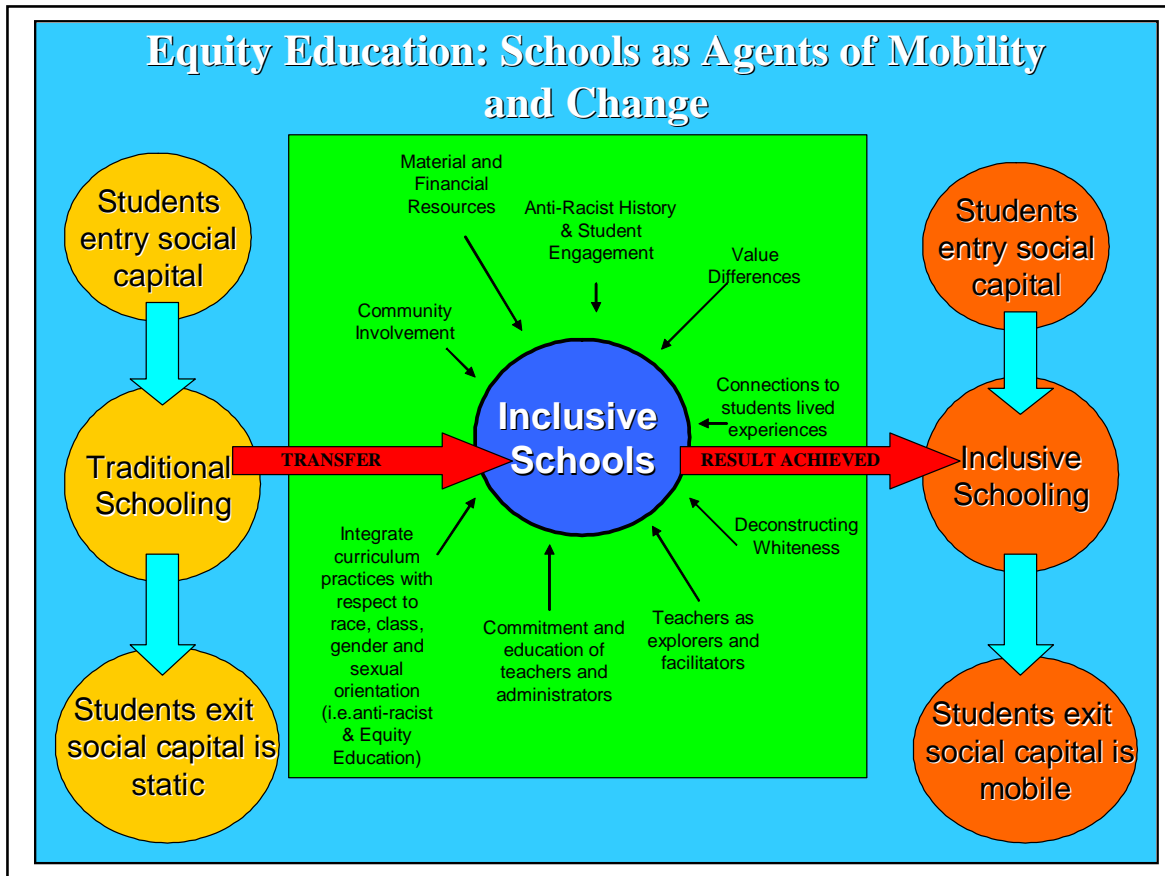

There is overwhelming evidence that schools reinforce and reproduce social inequities within society (Bourdireu, 1986; Lewis, 2003; Merten, 1997; Wang, 2000). In Bourdieu's theory, social capital is defined as personal assets which provide substantial advantages to those who are connected through a network of established relationships. Ideally schools should not recreate inequities that already exist in society but should be agents for change and opportunity. Key factors enabling schools in becoming agents of mobility and opportunity are pedagogies of 'whiteness', teacher education, representative curriculum, addressing radicalization and culture, and modified instruction techniques. Understanding these variables will go a long way in, providing educators with the requisite information necessary to take first steps toward eradicating racism and inequity currently existing in our school systems.

(C) 2004

Figure 3. The examples of conceptual frameworks used in C-FLO

\section{Impact on Student Learning}

C-FLO has been in existence since July, 2004 and used by learners since that time. Evidence for the utility and effectiveness of C-FLO was gathered from a number of sources, including (1) letters and emails from the learners to the professor describing how they had used C-FLO and the benefits they derived from it; (2) the professor's observations regarding the quality of the conceptual frameworks produced as assessed against a performance rubric; (3) analysis of emails and discussion postings in which learners requested help as they developed their frameworks; and (4) course evaluation data.

There are many compelling examples and strong evidence of how C-FLO facilitated learning both as a stand alone product that enhances M.A. students' and Ph.D. students' development of a conceptual framework and as a resource embedded in a course. Those students reported that they found C-FLO to be a fun and engaging learning experience. The following excerpts from letters and emails highlight this: 
[C-FLO is] good to maintain interest and easy to use. (M.Ed. student)

The learning object included texts, videos, graphics and examples. It was amazing. (M.Ed. student)

I am currently working on my philosophy of education. Thank you for the link, C-FLO is very helpful. It is a great site. It is very creative yet informative at the same time. (B.Ed. student)

The learning object is well structured and pleasing to the eye. (Ph.D. candidate)

The video clips and range of examples discussing various aspects of the framework gave a sense that a community of learners exists, rather than one who is stranded studying on an island alone. (M.A. student)

The C-FLO allowed me to take an active and self-directed role in the conceptualisation and development of my conceptual framework. (M.Ed. student)

With C-FLO, the information and knowledge gained is understood, absorbed, and retained. C-FLO peaked [sic] my interest, stimulated my learning, provided an inner motivation and served to increase the effectiveness and efficiency of my learning. Beyond the educational advantages and effects of C-FLO, it permitted me to work as a self-directed learner while still being employed. (M.Ed. student)

Several learners indicated that C-FLO improved their learning and facilitated the process of developing a conceptual framework. One learner explained, "We did not start from scratch. By looking at those examples we could identify what should be included in the conceptual framework and the relationship between those factors”. A Ph.D. student rued:

"I wish I had known about this website at the early stage of my research as it would have saved me a lot of time in coming to terms with how to systematically go about doing research. As I went through the website I realised that I have actually gone through almost all the stages by trial and error, which is the hard way of course!”

Learners repeatedly mentioned two aspects of C-FLO as being especially helpful to their learning: the conceptual framework examples and the narrators' recounting of her experiences. One learner related:

“It is always a good idea to learn about others' experiences. Her discussion provided us the right direction and we did not have to spend much time figuring out what troubled us. The expectations of a conceptual framework were made clear and the objectives of the learning object were also clear. The examples provided a good indication of expectations both visually and for the written component. I was able to travel through the map at my own pace and go back as much as I desired. The most helpful parts were the working drafts, which clearly demonstrated that a conceptual framework is a work in process. The examples were also helpful. The learning object demystified the development of a conceptual framework by providing examples, drafts, a live student experience, and steps. It was useful to hear the experience of a peer because she went through what I was going through, therefore I could relate.”

Another learner shared a similar experience:

"Following the proposed steps helped me document my thoughts and then structure them into a useful guide. The examples provided were key in anchoring my understanding of conceptual frameworks and I still refer to the examples regularly as a source of inspiration. This learning object not only provided me with the basic knowledge necessary to create a conceptual framework, the video clips offered encouraging advice and insight 
into the process. Following someone else's journey somehow made the task less intimidating. This learning object has become a companion and an important resource to help me in my doctoral endeavours."

Convincing evidence that the C-FLO achieved its objectives and facilitated the conceptual framework development process is the learners' conceptual frameworks themselves. As is evident from a perusal of these final products, learners produced professional looking, well-written, comprehensive conceptual frameworks that go beyond the expectations for an M.Ed. course. More specifically, a rubric was used to assess and report on the quality of the conceptual frameworks (see Table 1). This rubric outlines six main quality criteria and three levels of performance outcome and clearly distinguishes between major and minor revisions.

Table 1. Assessment rubric for conceptual framework

\begin{tabular}{|l|l|l|l|}
\hline \multicolumn{1}{|c|}{ Criteria } & $\begin{array}{c}\text { Requires Major Re- } \\
\text { visions }\end{array}$ & $\begin{array}{l}\text { Requires Minor Re- } \\
\text { visions }\end{array}$ & \multicolumn{1}{|c|}{ Acceptable } \\
\hline $\begin{array}{l}\text { Alignment between } \\
\text { diagram and write up }\end{array}$ & $\begin{array}{l}\text { Alignment between } \\
\text { diagram and write-up } \\
\text { not apparent. Several } \\
\text { things in diagram not } \\
\text { described in write up } \\
\text { or visa versa }\end{array}$ & $\begin{array}{l}\text { Few mistakes in } \\
\text { alignment between } \\
\text { diagram and write-up }\end{array}$ & $\begin{array}{l}\text { Everything in the dia- } \\
\text { gram is described in } \\
\text { the paper and every- } \\
\text { thing in the write-up } \\
\text { can be seen in the dia- } \\
\text { gram }\end{array}$ \\
\hline $\begin{array}{l}\text { Aesthetically pleasing } \\
\text { diagram }\end{array}$ & $\begin{array}{l}\text { Diagram not in com- } \\
\text { puter software, not } \\
\text { attractive }\end{array}$ & $\begin{array}{l}\text { Attractive diagram } \\
\text { that needs minor } \\
\text { tweaking }\end{array}$ & $\begin{array}{l}\text { Attractive diagram } \\
\text { with good use of } \\
\text { graphics and colour }\end{array}$ \\
\hline $\begin{array}{l}\text { Clear research vari- } \\
\text { ables }\end{array}$ & $\begin{array}{l}\text { Variables not opera- } \\
\text { tionalised }\end{array}$ & $\begin{array}{l}\text { Good description of } \\
\text { variables with minor } \\
\text { explanations required }\end{array}$ & $\begin{array}{l}\text { All variables de- } \\
\text { scribed adequately }\end{array}$ \\
\hline $\begin{array}{l}\text { Relationship among } \\
\text { variables apparent }\end{array}$ & $\begin{array}{l}\text { Relationship among } \\
\text { variables not evident }\end{array}$ & $\begin{array}{l}\text { Minor editing needed } \\
\text { to clarify relationships }\end{array}$ & $\begin{array}{l}\text { Clear relationship } \\
\text { evident between and } \\
\text { among variables }\end{array}$ \\
\hline $\begin{array}{l}\text { Succinct write up de- } \\
\text { scribing the diagram }\end{array}$ & $\begin{array}{l}\text { Write up too long and } \\
\text { convoluted. Unclear }\end{array}$ & $\begin{array}{l}\text { Clear writing, needs } \\
\text { minor editing }\end{array}$ & $\begin{array}{l}\text { Clear writing describ- } \\
\text { ing all variables in the } \\
\text { diagram }\end{array}$ \\
\hline $\begin{array}{l}\text { Presentation of mate- } \\
\text { rial }\end{array}$ & $\begin{array}{l}\text { Writing unclear, not } \\
\text { attentive to APA writ- } \\
\text { ing style, grammar } \\
\text { and spelling mistakes }\end{array}$ & $\begin{array}{l}\text { Minor grammar or } \\
\text { spelling errors, minor } \\
\text { APA mistakes }\end{array}$ & $\begin{array}{l}\text { Clear writing, correct } \\
\text { grammar and spelling, } \\
\text { correct use of APA }\end{array}$ \\
\hline
\end{tabular}

The professor reported that the first drafts of the conceptual frameworks from these learners were better than in the previous years when learners did not have access to C-FLO. All 15 students in the completed course with C-FLO produced conceptual frameworks on their first attempt. Those conceptual frameworks required only minor revisions for inclusion in their final synthesis paper.

As Table 2 illustrates, this degree of quality on the first draft is something that had never occurred in previous offerings of the course. One M.Ed. student wrote:

"Because of the effectiveness of C-FLO, I was able to develop a comprehensive conceptual framework. I was requested to complete only minor modifications following the submission of my initial draft. The conceptual framework allowed me to clarify the structure of my paper early on, thus considerably facilitating the writing process”. These find- 
ings suggest that C-FLO may save both the learner and the professor time. Indeed, one learner noted, "I had no idea about conceptual frameworks at first. However, the learning object made the process easier and faster”.

Table 2. Percentage of learners who needed to make major revisions to the first draft of their conceptual frameworks

\begin{tabular}{|l|c|c|}
\hline \multicolumn{1}{|c|}{ Course } & $\begin{array}{c}\text { \# students in } \\
\text { course }\end{array}$ & $\begin{array}{c}\text { Percentage of learners who needed to } \\
\text { make major revisions to the first draft of } \\
\text { their conceptual frameworks }\end{array}$ \\
\hline $\begin{array}{l}\text { EDU5199 - Fall 2002 } \\
\text { Before C-FLO }\end{array}$ & 19 & 74 \\
\hline $\begin{array}{l}\text { EDU5199 - Fall 2003 } \\
\text { Before C-FLO but in- } \\
\text { cluding online examples }\end{array}$ & 32 & 47 \\
\hline $\begin{array}{l}\text { EDU5199 - Fall 2004 } \\
\text { After C-FLO }\end{array}$ & 15 & 0 \\
\hline
\end{tabular}

Moreover, an analysis of discussion postings and the learners' emails to the professor and discussion postings indicated that there was less stress, anxiety, and confusion amongst learners and far fewer questions regarding how to develop a conceptual framework than when the learners had had to develop a conceptual framework without the support of C-FLO. Table 3 highlights a decrease in the number of questions regarding the conceptual framework development process the learners asked the professor after the introduction of C-FLO.

Table 3. Number of learner emails to professor with questions relating to the development of conceptual frameworks.

\begin{tabular}{|l|c|c|}
\hline \multicolumn{1}{|c|}{ Course } & $\begin{array}{c}\text { \# students in } \\
\text { course }\end{array}$ & $\begin{array}{c}\text { Average \# emails per learner sent to } \\
\text { professor with questions related to } \\
\text { conceptual frameworks }\end{array}$ \\
\hline $\begin{array}{l}\text { EDU5199-Fall 2002 } \\
\text { Before C-FLO }\end{array}$ & 19 & 1.42 \\
\hline $\begin{array}{l}\text { EDU5199-Fall 2003 } \\
\text { Before C-FLO but in- } \\
\text { cluding online examples }\end{array}$ & 32 & 0.94 \\
\hline $\begin{array}{l}\text { EDU5199-Fall 2004 } \\
\text { After C-FLO }\end{array}$ & 15 & 0.53 \\
\hline
\end{tabular}

By providing criteria for expected rigor and examples of completed products, C-FLO provided a standard that facilitated the creation of quality conceptual frameworks on the learners' first drafts. Not only did this mean less work and time for learners in revising and reworking their conceptual frameworks, but also less work and time for the professor marking and providing feedback to learners. Further, learners were more confident and able to readily engage in a higher level of discussion with others regarding the content of their conceptual framework.

One last piece of evidence that supports the positive impact C-FLO had on the learning experience is the overall course rating from the course evaluations completed by the learners in EDU5199. Figure 4 illustrates the teaching scores (1 - very poor; 2 - poor; 3 - acceptable; 4 good; 5 - excellent) on the P report (Q6 - I find that the professor as a teacher is; Q8 - I think the professor conveys the subject matter; Q9 - I find the professor well prepared for class; Q12 When I need to consult with the professor outside class, I find him/her available during scheduled 


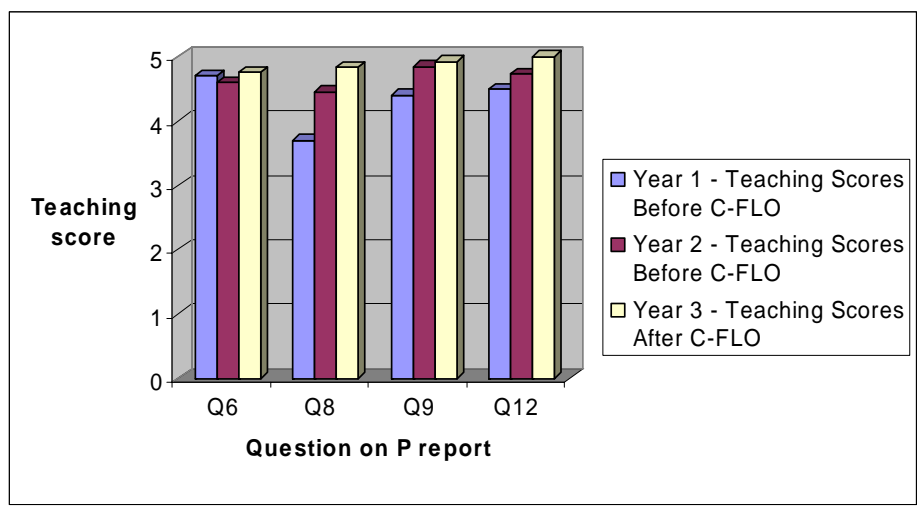

Figure 4. Teaching scores for EDU5199 before and after the introduction of C-FLO office hours and/or at prearranged times) over a three year period before and after the integration of C-FLO. Although there could be other reasons to explain the increase in scores, the data indicates a positive increase in teaching scores after C-FLO was implemented into EDU5199 in Fall, 2004.

\section{Future Developments}

The feedback from the learners who have used C-FLO has been extremely positive. At the same time, the interest that is currently been shown in the wider dissemination of this learning object is phenomenal and continues to grow rapidly. In addition to its original location on the web (http://innovation.dc-uoit.ca/cloe/lo/cf/), C-FLO has recently been made available through the CLOE learning repository and can be accessed at http://cloe.on.ca . CLOE is a pan-Canadian repository for learning objects established to facilitate the exchange of learning objects between universities. The goal is to create a collaborative educational program by encouraging learning objects to be shared and used in classrooms across Canada. Member institutions develop learning objects that are available on a reciprocal basis; faculty may both use and contribute materials to the repository. The learning objects go through a peer review process to ensure the learning materials meet the most rigorous standards both for learning object design and academic discourse. The attention to the peer review process within CLOE differentiates it from disparate content found throughout the Internet.

C-FLO is also available through MERLOT (Multimedia Educational Resource and Online Teaching; www.merlot.org ). MERLOT is another learning object repository that facilitates the free exchange of learning objects designed for faculty and students enrolled in secondary or postsecondary education. Educators from across the globe may access the repository and use materials (learning objects) for educational purposes based on an open license arrangement. MERLOT, like CLOE, ensures materials meet standards for academic integrity while also ensuring the learning objects meet emerging standards for learning object design.

Finally, C-FLO can also be accessed from the UofO's Centre for University Teaching's website. The Centre for University Teaching provides pedagogical programs and services for members of the academic community to promote and provide support for the development and provision of the highest quality teaching throughout the university. Over 1,000 faculty and 30,000 students at the university have access to this site.

Response is enthusiastic when C-FLO is explained or demonstrated. For example, when the existence of C-FLO was recently made known in a thesis proposal in the Faculty of Education at the UofO, every professor and M.A. and Ph.D. student in the room expressed a need for the learning object and several requested the link. A professor from the Second Language Institute at the UofO revealed, 
"Earlier this week, I forwarded the information about your work on conceptual frameworks to my Ph.D. students. I am sure they will find it very helpful. Many thanks again for sharing this work with us.”

The Director of an e-learning Initiative in South Australia writes:

"I believe it [C-FLO] would prove useful in an Australian Higher Education context. In the somewhat conservative field of teacher education this stands out as innovative and useful, drawing both teachers and students into a world of reuse, reflection, and reconceptualization.”

Lastly, C-FLO was recently demonstrated at a meeting of healthcare professionals and many individuals in the room expressed an interest in implementing C-FLO into their courses in nursing, medicine, and pharmacy. The Curriculum Coordinator from provincial Health Care Nurse Practitioner Program writes:

The Conceptual Frameworks Learning Object was easy to navigate and interactive with multi media. The content has potential to be incorporated into a number of other programs. I have forwarded the example to the course professors in the program for their review. I am seeking their suggestions as to how this can be incorporated into this educational program.

\section{Conclusions and Recommendations}

The collaborative project described in this paper resulted in a product that improved student learning and ability to develop a comprehensive conceptual framework; provided an engaging and enjoyable learning experience for learners; reduced the stress and anxiety learners commonly associate with the task of developing a conceptual framework; and produced higher quality work than the professor had previously observed among learners before the availability of C-FLO. CFLO provides a timely and important contribution by providing information in a "building block" format accessible to learners requiring "just in time" acquisition of knowledge and skills to help them succeed in developing conceptual frameworks to facilitate the writing of research papers, reports, and theses. C-FLO can be used as a stand-alone product, embedded into online courses, or employed as a support resource in face-to-face courses and programs.

A number of lessons emerged from the experience of designing and developing C-FLO that may benefit other teams who are considering developing online learning objects:

1. Select your team strategically so that team members' strengths, knowledge, skills, and expertise complement one another. The result will be a far better learning product than would be possible if the members worked independently.

2. Define the team members' roles and responsibilities clearly at the start of the project.

3. Involve learners in the design process. They will be able to provide valuable insight from the learners' perspective and highlight learners' needs. Learners' input may influence what content is emphasised in the learning object and the design of the activities in the learning process.

4. Involve a project champion who possesses passion, persistence, and the unwavering belief in the value of developing innovative learning experiences for learners.

5. Arrange for the team to spend time together early on in the project. This will allow for teambuilding and the conceptualization of the project, agreement of goals and objectives, exchange of ideas, and a general plan for what the end project will look like, how it will be developed, and the roles of the group members. 
6. If the learners are required to create something, provide an example(s) of the end product. This will help clarify expectations and set a quality standard for learners to meet or exceed.

7. The learning object and the activities within it should be fun and engaging. When the team explores creative ideas and challenges, it not only makes the design process exciting and enjoyable but results in a better quality product.

8. The use of a metaphor can enhance the learning process by providing context and helping the learners build bridges between the familiar and the new.

9. To avoid technology dictating the design process, first focus on the learning objective(s) and then the activities and assessments that will support them. You can then experiment with the metaphor and finally look at the technology tools and see how they will best support the learning objectives.

10. Pilot early versions of the learning object with learners to receive formative feedback to assist in fine tuning the design, including content and usability.

Traditionally, university professors have worked in isolation often replicating courses and resources across, and even within, institutions. Professors are often protective of their intellectual property and convincing some of them of the benefits of collaboration may require a paradigm shift. Not only can working in teams within and across faculties improve teaching, make better use of resources, and save time, the social facet of learning has been found to be a source of support and encouragement during learning (Stodel, 2004). Sharing our experiences regarding the development of C-FLO could be helpful to professors wanting to eliminate the eLearning Contradiction and meet the challenges of implementing technology solutions while managing their time and resources to enable them to excel in the university culture. Indeed, in some cases university faculty are encouraged to use technology both to support their on-campus courses and to support eLearning. Implementing C-FLO into a face-to-face course could meet the technology requirement of some faculties with little or no effort on the part of the professor. In short, collaborative projects such as C-FLO where professors share resources and expertise to improve student learning could be a first step toward addressing the eLearning Contradiction.

\section{References}

Ally, M. (2004). Designing effective learning objects. In R. McGreal (Ed.), Online education using learning objects (pp. 87-97). London: RoutledgeFalmer.

Burge, E. J. (2001a). Using learning technologies: A synthesis of challenges and guidelines. In E. J. Burge \& M. Haughey (Eds.), Using learning technologies: International perspectives on practice (pp. 145155). London: Routledge Falmer.

Burge, E. J. (2001b). The strategic use of learning technologies. New directions in adult and continuing education, \# 88. San Francisco, CA: Jossey-Bass/Wiley.

Burge, E. J., \& Haughey, M. (2001). Using learning technologies: International perspectives on practice. London: Routledge Falmer.

Canada, M. (2000). Students as seekers in online courses. In R. E. Weiss, D. S. Knowlton, \& B. W. Speck (Eds.), Principles of effective teaching in the online classroom, No. 84 (pp. 35-40). San Francisco, CA: Jossey-Bass.

Conference Board of Canada. (2000). Solutions for employers: Effective strategies for using learning technologies in the workplace. Retrieved September 27, 2002 from http://www.conferenceboard.ca/education/pdf/solutions1.pdf

Conference Board of Canada. (2001). ELearning for the workplace: Creating Canada's lifelong learners. Retrieved September 27, 2002 from http://www.conferenceboard.ca/education/pdf/eLearning for the workplace.pdf 
DeBard, R., \& Guidera, S. (2000). Adapting asynchronous communication to meet the seven principles of effective teaching. Journal of Educational Technology Systems, 28 (3), 219-230.

Downes, S. (2004). Learning objects resources for learning worldwide. In R. McGreal (Ed.), Online education using learning objects (pp. 21-31). London: RoutledgeFalmer.

Drucker, F. P. (1997). The organization of the future. San Francisco, CA: Jossey-Bass.

Eastmond, D., \& Ziegahn, L. (1995). Instructional design for the online classroom. In Z. L. Berge \& M. P. Collins (Eds.), Computer mediated communication and the online classroom, Vol. III: Distance learning (pp. 59-80). Cresskill, NJ: Hampton Press.

Fitch, J.L. (2004). Student feedback in college classroom: A technology solution. Educational Technology Research and Development, 52 (1), 71-81.

Gibbons, A. S., Nelson, J., \& Richards, R. (2000). The nature and origin of instructional objects. In D. A. Wiley (Ed.), The instructional use of learning objects [Electronic version]. Retrieved December 15, 2004 from http://reusability.org/read/chapters/gibbons.doc

Haughey, M., \& Anderson, T. (1998). Networked learning: The pedagogy of the Internet. Toronto, ON: McGraw-Hill.

Hill, J. R. (1997). Distance learning environments via the world wide web. In B. H. Khan (Ed.), Web-based instruction (pp. 75-80). Englewood Cliffs, NJ: Educational Technology.

Hodgins, H. W. (2000). Into the future: A vision paper. Retrieved December 15, 2004 from http://www.learnativity.com/download/MP7.PDF

Hunt, M., Parsons, D., \& Fleming, A. (2003). A review of the research literature on the use of managed learning environments and virtual learning environments in education, and a consideration of the implications for schools in the United Kingdom. Retrieved January 9, 2005 from http://www.becta.org.uk/page_documents/research/VLE_report.pdf

Jonassen, D. H. (1994). Thinking technology: Toward a constructivist design model. Educational Technology, 34 (4), 34-37.

Jonassen, D. H., Peck, K. L., \& Wilson, B. G. (1999). Learning with technology: A constructivist perspective. Upper Saddle River, NJ: Prentice Hall.

Kearsley, G. (1996, Winter). The World Wide Web: Global access to education. Educational Technology Review, 5, 26-30.

Khan, B. H. (1997). Web-based instruction (WBL): What is it and why is it? In B. H. Khan (Ed.), Webbased instruction (pp. 5-18). Englewood Cliffs, NJ: Educational Technology.

Land, S. M., \& Hannafin, M. J. (2000). Student-centered learning environments. In D. H. Jonassen \& S. M. Land (Eds.), Theoretical foundations of learning environments (pp. 1-23). Mahwah, NJ: Lawrence Erlbaum Associates.

MacDonald, C. J., \& Gabriel, M. A. (1998). Toward a partnership model for web-based learning. The Internet and Higher Education, 1 (3), 203-216.

MacDonald, C. J., Stodel, E. J., Farres, L. G., Breithaupt, K., \& Gabriel, M. A. (2001). The DemandDriven Learning Model: A framework for web-based learning. The Internet and Higher Education, 4 (1), 9-30.

MacDonald, C. J., \& Thompson, T. L. (2004). Structure, content, delivery, service, and outcomes: Quality e-learning. Manuscript submitted for publication.

McConnell, D. (2002). The experience of collaborative assessment in eLearning. Studies in Continuing Education, 23 (1), 73-92.

McGorry, S. Y. (2003). Measuring quality in online programs. The Internet and Higher Education, 6 (2), 159-177. 
Moe, M. T., \& Gay, R. K. (1997). Profiting from the failure of higher education: Demolishing the ivy halls and building classrooms without walls. In The dawn of the age of knowledge education industry (pp. 37). Nations Bank Montgomery Securities, Research Report 1st Quarter, April, 1997.

Muirhead, W., \& Haughey, M. (2003). An assessment of the learning objects, models and frameworks developed by The Learning Federation Schools Online Curriculum Content Initiative. Australia: The Learning Federation.

Parrish, P. E. (2004). The trouble with learning objects. Educational Technology Research and Development, 52 (1), 49-67.

Porter, D., Curry, J., Muirhead, W., \& Galan, N. (2002). Report on learning object repositories: Review and recommendations for a pan-Canadian approach to repository implementation in Canada. Ottawa, ON: CANARIE and Industry Canada.

Relan, A., \& Gillani, B. B. (1997). Web-based instruction and the traditional classroom: Similarities and differences. In B. H. Khan (Ed.), Web-based instruction (pp. 41-46). Englewood Cliffs, NJ: Educational Technology.

Richards, G., \& Hatala, M. (2003). Interoperability frameworks for learning object repositories. In A.M. Vilas, J.A.M. Gonzalez, \& J.M. Gonzales (Eds.). Advances in technology-based education: Toward a knowledge-based society (pp. 366-372). Badajoz: Junta de Extremadura, Consejera de Education.

Romiszowski, A. J. (1997). Web-based distance learning and teaching: Revolutionary invention or reaction to necessity? In B. H. Khan (Ed.), Web-based instruction (pp. 25-37). Englewood Cliffs, NJ: Educational Technology.

Salmon, G. (2000). E-moderating: The key to teaching and learning online. London: Kogan Page.

Smaldino, S. (1999). Instructional design for distance education. Techtrends, 43 (5), 9-13.

Stodel, E. J. (2004). Mental training for enjoyment: Exploring the experiences, processes, and outcomes with recreational golfers. Unpublished doctoral dissertation, University of Ottawa, Ottawa, Ontario, Canada.

Stodel, E. J., \& Farres, L. G. (2002). Insights for delivering mental skills training over the web. Journal of Excellence, 6, 104-117.

Urdan, T. A. \& Weggen, C. C. (2000). Corporate e-learning: Exploring a new frontier. Retrieved December 15, 2004 from http://wrhambrecht.com/research/coverage/elearning/ir/ir_explore.pdf

Wagner, E. D. (1997). Interactivity: From agents to outcomes. New Directions for Teaching and Learning, $71,19-26$.

Wiley, D. A. (2000). Connecting learning objects to instructional design theory: A definition, a metaphor, and a taxonomy. In D. A. Wiley (Ed.), The instructional use of learning objects [Electronic version]. Retrieved December 15, 2004 from http://reusability.org/read/chapters/wiley.doc

\section{Biographies}

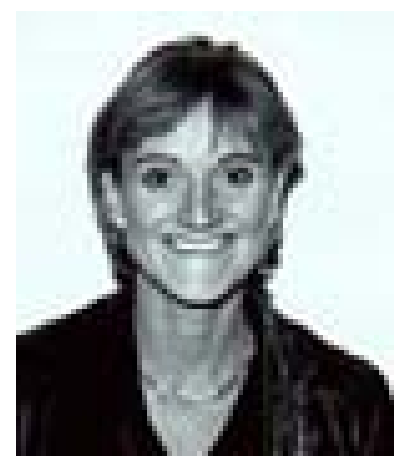

Dr. Colla J. MacDonald is a Professor in the Faculty of Education at the University of Ottawa. Her research concentrates on eLearners and eLearning environments. She supervises graduate students working in the area of eLearning and has published the Demand-Driven Learning Model (DDLM) (a model for designing superior e-learning) and a companion online survey to evaluate e-learning courses and programs. She has designed and taught several online courses including one that won the WebCT Exemplary Course Award. 


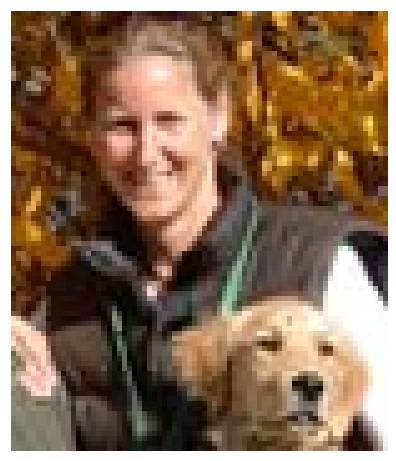

Dr. Emma Stodel is a Post-Doctoral Fellow in the Faculty of Education at the University of Ottawa. Her research is dedicated towards developing a better understanding of the e-learning process from design through to evaluation and providing guidelines for the effective practice of e-learning. Dr. Stodel was a key partner in the development of two e-learning models: the Demand-Driven Learning Model and WebExcellence in Mental Skills Education.

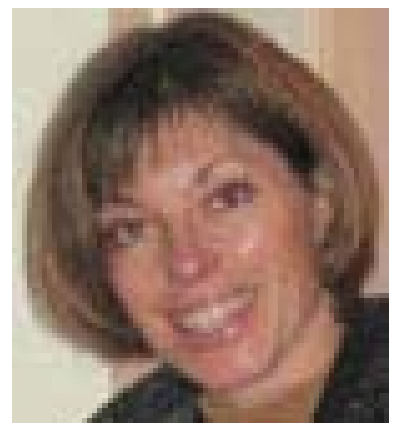

Terrie Lynn Thompson. As a learning consultant, her focus is on helping people and organizations become better at learning - especially e-learning. Her background includes management, research, facilitation, and instructional design in a range of settings: international, not-for-profit sport, high tech, and higher education. She has been involved in research projects exploring quality e-learning initiatives. As the Learning Director for Digital Opportunity Trust, a Canadian-based NGO, she currently develops innovative international ICT and Development learning experiences for youth leaders and community members in developing countries.

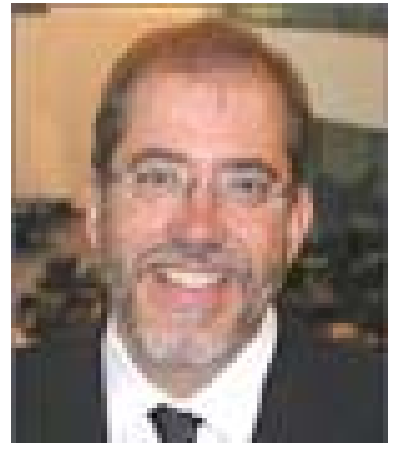

Dr. Bill Muirhead is currently Associate Provost, Learning Technologies, University of Ontario, Institute of Technology. With extensive experience online education, course development and international education, Bill has received many awards. Bill is currently President of the Canadian Association for Distanced Education and Editor in Chief of the Collaborative Learning Object Exchange.

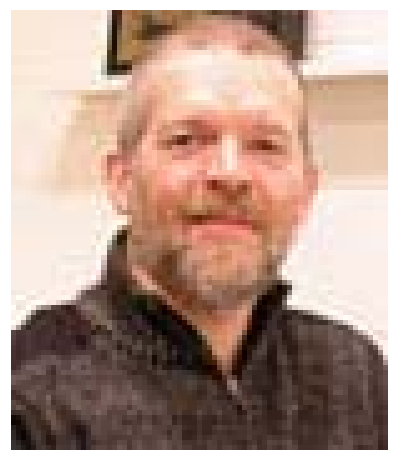

Chris Hinton is the Director of the Centre for Academic Excellence and Innovation at UOIT and Durham College. He manages projects and day-to-day activities in the Centre and has played a design and project management role in the development of learning objects. The Centre works with faculty on professional development and the appropriate use of pedagogy for teaching and learning. He is the chair of the provincial Educational Technology Committee and a project manager with CLOE. 


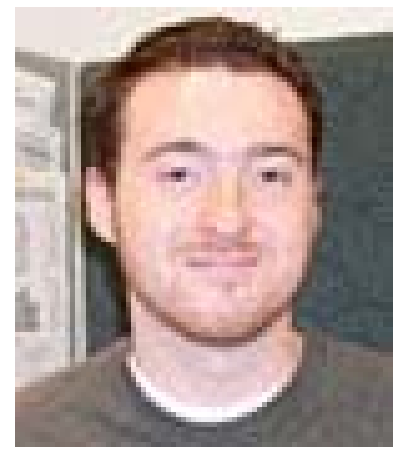

Brad Carson is an E-Learning Content Developer in the Centre for Academic Excellence and Innovation at UOIT and Durham College. He provides training and technical support for faculty and staff, and participates in the creation of interactive course content designed to enhance the teaching and learning experience. As part of the team at the Centre he has developed learning objects on several topics including: conceptual frameworks, plagiarism and effective decision making to guide classroom behaviour.

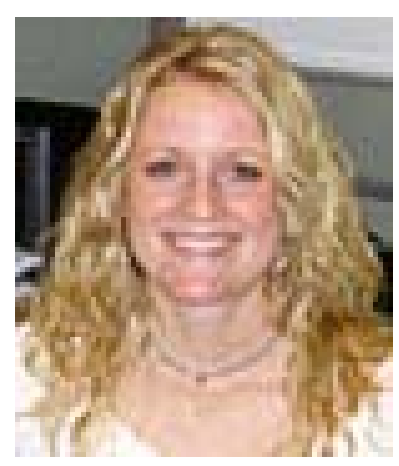

Erin Banit is a Multimedia Developer at the Centre for Academic Excellence and Innovation at UOIT and Durham College. On a daily baas well as their professional development in various technology areas. She has worked on a number of specific projects with faculty creating learning objects and other multimedia content to help enhance the elearning experience of their students. sis she assists staff and faculty with a wide range of multimedia needs, 